\title{
Direct Access to Parent Amido Complexes of Rhodium and Iridium through N-H Activation of Ammonia**
}

\author{
Inmaculada Mena, Miguel A. Casado, * Pilar García-Orduña, Víctor Polo, Fernando J. Lahoz, Atif \\ Fazal and Luis A. Oro*
}

((Dedication----optional))

Ammonia is a low-cost and potentially valuable building block for almost every nitrogen-containing compound required by industry. There is an obvious interest in taking advantage of this chemical as feedstock in catalytic organic transformations to produce higher value products, issue that has began to be explored with some degree of success. ${ }^{[1]}$ However, most of late transition metal catalyzed reactions do not occur with ammonia. Several factors have been invoked to explain this lack of reactivity: ${ }^{[2]}(i)$ the high strength of the N-H bond of ammonia $\left(107 \mathrm{kcal} \mathrm{mol}^{-1}\right)$ makes its activation very hard to be achieved by metal centres, (ii) the catalyst often deactivates through the formation of stable Werner ammine ( $\mathrm{M} \leftarrow \mathrm{NH}_{3}$ ) adducts, and (iii) the low acidity of ammonia prevents its participation in proton exchange reactions that could lead to $\mathrm{N}-\mathrm{H}$ activation.

In order to achieve a metal-mediated functionalization of ammonia, an imperative requisite should be the formation of $\mathrm{M}-\mathrm{NH}_{2}$ bonds directly from ammonia (i.e. rather than leading to stable $\mathrm{M} \leftarrow \mathrm{NH}_{3}$ adducts). ${ }^{[3]}$ So far, only few early examples involving interaction of $\mathrm{NH}_{3}$ with iridium complexes followed an oxidative addition profile. ${ }^{[4]}$ This concept was elegantly illustrated by Hartwig et al., who reported on the formal oxidative addition of ammonia to an electron rich $\operatorname{Ir}^{\mathrm{I}}$ pincer system, leading to the first structurally characterized terminal amido hydrido Ir ${ }^{\mathrm{III}}$ complex. ${ }^{[5]}$ In spite of the beauty and simplicity of this N-H activation, uptake and homolytic breakage of ammonia by late transition metal complexes still remains a difficult goal. ${ }^{[6]}$ We believed that a good approach to induce the formation of $\mathrm{M}-\mathrm{NH}_{2}$ bonds, circumventing the formation of Werner adducts, should rely on an appropriate design of

[*] Dipl. Chem. I. Mena, Dr. M. A. Casado, Dra. P. GarcíaOrduña, Prof. F. J. Lahoz, Prof. L. A. Oro Instituto de Síntesis Química y Catálisis Homogénea ISQCH, Universidad de Zaragoza-CSIC

PI. San Francisco s/n, 50009 Zaragoza (Spain)

Fax: (+ 34) 976-761-187

E-mail:mcasado@unizar.es, oro@unizar.es

Dr. V. Polo

Departamento de Química Física, Universidad de Zaragoza 50009 Zaragoza

Dr. A. Fazal, Prof. L. A. Oro (KFUPM Visiting Professor) Center for Refining \& Petrochemicals, King Fahd University of Petroleum \& Minerals, Dhahran 31261, Saudi Arabia [**] Financial support from CONSOLIDER INGENIO-2010 program under the projects MULTICAT (CSD2009-00050) and Factoría de Cristalización (CSD2006-0015). PGO acknowledges financial support from the CSIC 'JAE-Doc' program.

Supporting information for this article is available on the WWW under http://www.angewandte.org or from the author organometallic precursors. Herein we report on a synthetic protocol that uses gaseous ammonia as " $\mathrm{NH}_{2}$ " source to generate stable novel parent bridging and terminal amido $\mathrm{Rh}^{\mathrm{I}}$ and $\mathrm{Ir}^{\mathrm{I}}$ complexes under very mild conditions.

We chose as metallic precursors dinuclear complexes bearing alkoxo-bridging ligands, well suited to induce N-H activation. ${ }^{[7]}$ In this way, treatment of the methoxo-bridged compounds $[\{\mathrm{M}(\mu-$ $\left.\mathrm{OMe})(\mathrm{tfbb})\}_{2}\right](\mathrm{M}=\mathrm{Rh}$, Ir; tfbb = tetrafluorobenzobarrelene $)$ with gaseous ammonia in diethyl ether at atmospheric pressure, rapidly afforded the parent amido-bridged trinuclear complexes $\left[\left\{\mathrm{M}\left(\mu_{2^{-}}\right.\right.\right.$ $\left.\left.\mathrm{NH}_{2}\right)(\mathrm{tfbb})\right\}_{3}$ ] $(\mathrm{M}=\mathrm{Rh}(\mathbf{1}), \operatorname{Ir}(\mathbf{2}))$, isolated in good yields. On the other hand, reactions of the cod complexes $\left[\{\mathrm{M}(\mu-\mathrm{OMe})(\mathrm{cod})\}_{2}\right]$ ( $\operatorname{cod}=1,5$-cycloctadiene) with gaseous ammonia yielded dinuclear amido-bridged complexes $\left[\left\{\mathrm{M}\left(\mu-\mathrm{NH}_{2}\right)(\operatorname{cod})\right\}_{2}\right](\mathrm{M}=\mathrm{Rh}(3), \operatorname{Ir}(4))$ in excellent yields (Scheme 1). All the reactions leading to complexes 1-4 were found to be reversible. For example, monitoring by NMR spectroscopy the reaction of $\mathbf{3}$ with $\mathrm{MeOH}$ in a 1:1 ratio in $\left[\mathrm{D}_{6}\right]$ benzene showed upon 10 minutes, when the equilibrium was considered to be reached, the presence of unchanged $\mathbf{3}$, the original methoxo-bridged complex $\left[\{\mathrm{Rh}(\mu-\mathrm{OMe})(\operatorname{cod})\}_{2}\right]$ and the mixed amido-alkoxo species $\left[\{\mathrm{Rh}(\mathrm{cod})\}_{2}(\mu-\mathrm{OMe})\left(\mu-\mathrm{NH}_{2}\right)\right]$ in a $0.4 / 0.3 / 1$ ratio respectively, along with released ammonia (see Supporting Information). Excess of substrates (i.e. $\mathrm{NH}_{3}$ or $\mathrm{MeOH}$ ) are required to drive the reactions to completion either way, as observed experimentally.

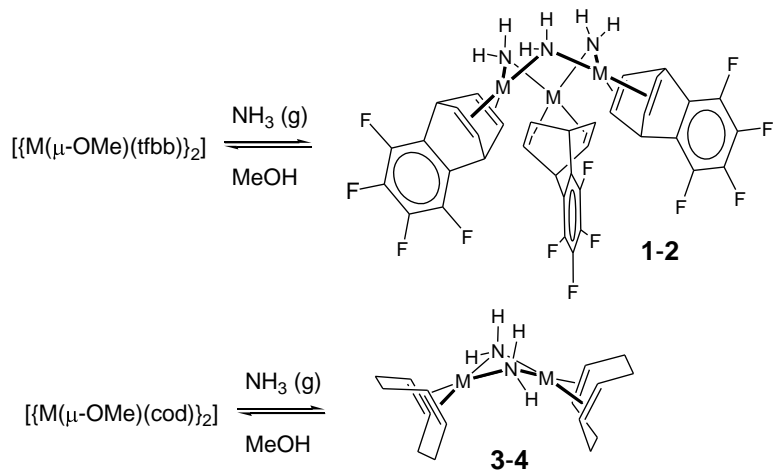

Scheme 1. Synthesis of parent amido-bridged complexes $[\{\mathrm{M}(\mu-$ $\left.\left.\left.\mathrm{NH}_{2}\right)(\mathrm{tfbb})\right\}_{3}\right]$ and $\left[\left\{\mathrm{M}\left(\mu-\mathrm{NH}_{2}\right)(\mathrm{cod})\right\}_{2}\right](\mathrm{M}=\mathrm{Rh}, \mathrm{Ir})$.

Complexes 1-4 have been fully characterized by elemental analysis, spectrometric techniques and multinuclear NMR $\left({ }^{1} \mathrm{H}\right.$, ${ }^{13} \mathrm{C}\left\{{ }^{1} \mathrm{H}\right\}$ and bidimensional $g$-HMQC $\left.{ }^{1} \mathrm{H}^{-}{ }^{15} \mathrm{~N}\right)$ data. Additionally, an $\mathrm{X}$-ray structural analysis has been carried out for complexes 1, 2 and $\mathbf{3}^{[8]}$ The most striking structural feature of these complexes relies on the different nuclearity of the tfbb compounds $\mathbf{1}$ and $\mathbf{2}$ in 
comparison to the cod complex $\mathbf{3}$, apparently only induced by the nature of the diolefin. Complexes $\mathbf{1}$ and $\mathbf{2}$ are trinuclear and isostructural, and exhibit three square-planar metal centers bridged by three $\mu_{2}-\mathrm{NH}_{2}$ groups, forming a $\mathrm{Rh}_{3} \mathrm{~N}_{3}$ six-membered metallacycle with a cone disposition. ${ }^{[9]}$ Intermetallic distances fall in the range 3.2043(3) - 3.3981(2) $\AA$ (1), and 3.2135(4) - 3.4222(4) $\AA$ (2), all of them excluding clear metal-metal interactions.

On the contrary, complex $\mathbf{3}$ is dinuclear, and crystallizes with two crystallographically independent but chemically identical molecules in the unit cell. The rhodium atoms lie on slightly distorted square-planar geometries and are held together by two amido bridging groups; the whole structure is folded around the N-N vector with dihedral angles of $68.36(6)^{\circ}$ and $58.45(7)^{\circ}$ between the two metal coordination planes of each molecule. The intermetallic separations (2.7785(3) and 2.8603(3) A) are much shorter than those observed in the tfbb analogs.

Theoretical calculations at the DFT level have been carried for amido di- and trinuclear complexes of $\mathrm{Rh}$ and Ir bearing tfbb and cod as ancillary ligands. The obtained gas-phase optimized geometries of structures 1-4 are in good agreement with X-ray values. Stationary points on the potential energy surfaces have been found for the experimentally unobserved trinuclear complexes of $\mathrm{Rh}$ and Ir bearing the cod ligand. These structures show a distortion from the $C_{3 \mathrm{v}}$ symmetry due to short hydrogen-hydrogen contacts $\left(\begin{array}{l}1.966 \AA \\ \AA\end{array}\right)$ between neighbouring cod units, pointing out a destabilization of trinuclear cod complexes due to steric repulsion. In contrast, such steric hindrance is reduced for trinuclear tfbb complexes due to the smaller size of the ligand (See Supporting Information).

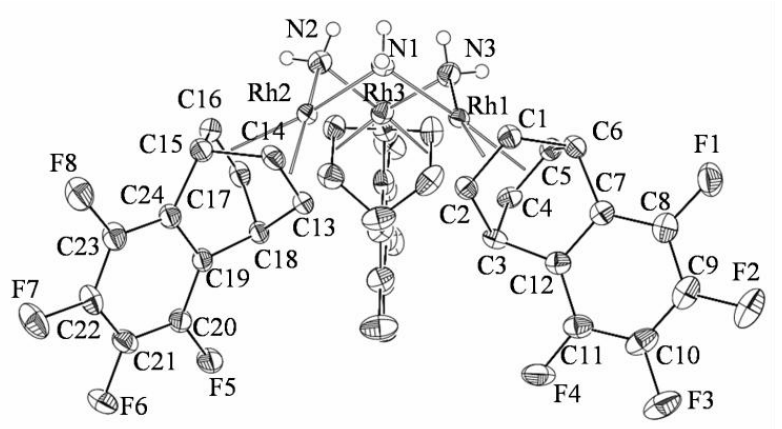

Figure 1. Molecular diagram of complex 1. Selected bonds distances (A) and angles $\left(^{\circ}\right)$ : Rh1-N1 2.058(2), Rh1-N3 2.075(3), Rh2-N1 2.089(2), Rh2-N2 2.066(3), Rh3-N2 2.084(3), Rh3-N3 2.068(3), mean Rh-Ct 2.001(3); N1-Rh1-N3 86.9(1), N1-Rh2-N2 88.1(1), N2-Rh3-N3 $88.4(1)^{\circ}$. Ct represents the midpoints of the olefinic bonds.

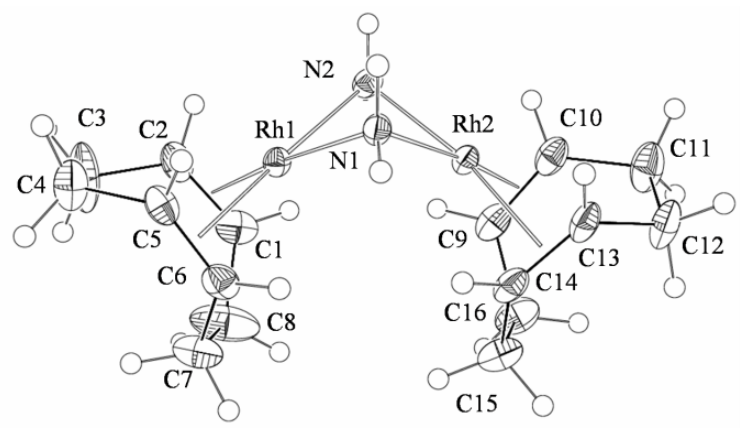

Figure 2. ORTEP diagram of complex 3. Selected bonds distances $(\AA)$ and angles $\left({ }^{\circ}\right)$ (only data for one independent molecule is stated here): Rh1-N1 2.092(2), Rh1-N2 2.078(3), Rh2-N1 2.088(2), Rh2-N2 2.064(2), mean Rh-Ct 2.003(5), N1-Rh1-N2 76.64(9), N1-Rh2-N2 76.95(10). Ct represents the midpoints of olefinic bonds.

Complexes 1-4 showed a temperature-dependent behavior in solution. At RT, both the ${ }^{1} \mathrm{H}$ and ${ }^{13} \mathrm{C}\left\{{ }^{1} \mathrm{H}\right\}$ NMR spectra of $\mathbf{1}$ and $\mathbf{2}$ showed two signals for the tfbb ligands $(\mathrm{CH}$ and $=\mathrm{CH}$ respectively), indicating an averaged $D_{3 \mathrm{~h}}$ symmetry, and a resonance due to the $\mathrm{NH}_{2}$ moiety at $0.35(\mathbf{1})$ and $2.67 \mathrm{ppm}(\mathbf{2})\left({ }^{15} \mathrm{~N}\right.$ NMR: $5.5(\mathbf{1}) ;-1.73$ ppm (2)). Cooling down the solutions of $\mathbf{1}$ and $\mathbf{2}$ led to the freezing of the fluxional motions, and single species with $C_{3 \mathrm{v}}$ symmetry were observed, according with the solid state structure found for both complexes. For instance, at $-50{ }^{\circ} \mathrm{C}$ the ${ }^{1} \mathrm{H}$ NMR spectrum of 1 showed the $\mathrm{CH}$ and $=\mathrm{CH}$ protons as sets of two resonances, while the amido protons were observed as two resonances at 0.23 and 0.44 ppm. This dynamic behavior responds to a fast exchange between the two possible conformers (cone and partial cone), which show approximately $C_{3 \mathrm{v}}$ and $C_{2}$ symmetries respectively. Line shape NMR variable temperature analysis allowed an estimation of the activation energy for the envelope flipping motions, which were 42.1 and 52.3 and $\mathrm{kJ} \mathrm{mol}^{-1}$ for complexes $\mathbf{1}$ and $\mathbf{2}$ respectively. These results are supported by gas-phase theoretical calculations (See Supporting Information). Partial cone structures of $\mathbf{1}$ and $\mathbf{2}$ have been found, being 17.1 and $20.0 \mathrm{~kJ} \mathrm{~mol}^{-1}$ less stable than the respective cone conformer. Transition structures have been found for the fluxional motion, yielding activation energies of 40.4 and $44.9 \mathrm{~kJ} \mathrm{~mol}^{-1}$ for $\mathbf{1}$ and $\mathbf{2}$ respectively, in good agreement with experimental values. On the other hand, the pattern of the ${ }^{1} \mathrm{H}$ and ${ }^{13} \mathrm{C}\left\{{ }^{1} \mathrm{H}\right\}$ NMR spectra of both cod complexes $\mathbf{3}$ and $\mathbf{4}$ at RT were similar to each other, indicating a dynamic motion which could not be frozen at $-90{ }^{\circ} \mathrm{C}$ in $\left[\mathrm{D}_{8}\right]$ toluene. The $D_{2 \mathrm{~h}}$ symmetry detected, in contrast to the expected $C_{2 \mathrm{v}}$ symmetry observed in the solid state, responded to a four-membered "MNMN" metallacycle inversion, ${ }^{[10]}$ which is fast on the NMR time scale therefore producing averaged NMR signals that reflected a planar conformation.

Access to terminal parent amido complexes of $\mathrm{Rh}^{\mathrm{I}}$ was straightforward by splitting the amido bridges of complex 1 with donor ligands, like dimethylphenylphosphane and the $\mathrm{N}$ heterocyclic carbene IPr (IPr = 1,3-bis $(2,6-$ diisopropylphenyl)imidazol-2-ylidene). Treatment of 1 with $\mathrm{PMe}_{2} \mathrm{Ph}$ in a 1:3 molar ratio gave $\left[\mathrm{Rh}(\mathrm{tfbb})\left(\mathrm{NH}_{2}\right)\left(\mathrm{PMe}_{2} \mathrm{Ph}\right)\right](5)$ in $61 \%$ yield. In a similar way, addition of IPr to $\mathbf{1}$ in a 3:1 molar ratio led to the formation of mononuclear complex $\left[\mathrm{Rh}(\mathrm{tfbb})(\mathrm{IPr})\left(\mathrm{NH}_{2}\right)\right](\mathbf{6})$ in $44 \%$ yield (Scheme 2). Complexes 5 and $\mathbf{6}$ featured an unprecedented $\mathrm{Rh}^{\mathrm{I}}-\mathrm{NH}_{2}$ moiety, which was confirmed by ${ }^{15} \mathrm{~N}-{ }^{1} \mathrm{H}$ HMQC spectroscopy $\left(\delta\left({ }^{1} \mathrm{H}\right)=-0.54(\mathbf{5}), 1.23 \mathrm{ppm}(\mathbf{6}) ; \delta\left({ }^{15} \mathrm{~N}\right)=-\right.$ $11.8(5), 67.6 \mathrm{ppm}(\mathbf{6}))$. The diolefins appeared as a set of three resonances in their ${ }^{1} \mathrm{H}$ NMR spectra, which indicated the presence of a mirror plane, while the tfbb: $\mathrm{NH}_{2}: \mathrm{L}\left(\mathrm{L}=\mathrm{PMe}_{2} \mathrm{Ph}\right.$, IPr) ratio was $1: 1: 1$ in both cases. In $\mathbf{6}$, the presence of a sole septuplet for the $i \mathrm{Pr}$ protons is explained taking into account the added effects of a rotational process that exchanges unsymmetrical isopropyl groups, and the mirror plane that bisects the imidazol ring of IPr and contains the Rh, $\mathrm{N}$ and the $\mathrm{C}$-carbenic atoms. ${ }^{[11]}$ 


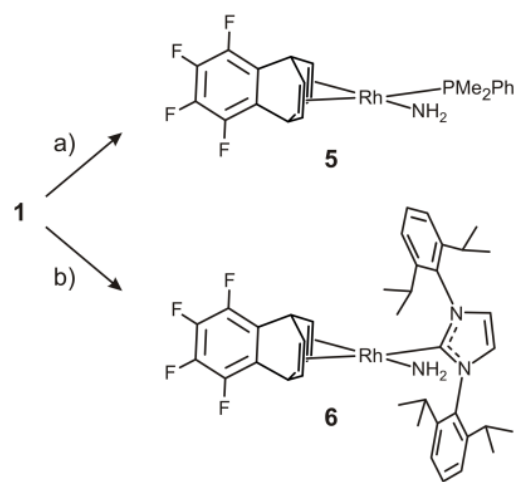

Scheme 2. Synthesis of complexes 5 and 6. a) $3 \mathrm{PMe}_{2} \mathrm{Ph}$, toluene, $15^{\circ} \mathrm{C}$; b) $3 \mathrm{IPr}$, toluene, RT.

In general, access to parent amido low-valent late transition metal complexes is rather limited, perhaps due to the absence of aromatic substituents at nitrogen, which adds stabilisation to the system by electronic delocalization. ${ }^{[12]}$ There are synthetic routes towards these compounds mainly based on salt metathesis reactions, ${ }^{[13-15]}$ however they need strong bases and do not use ammonia directly for their formation. Only few examples of these elusive species have been recently reported to be prepared from ammonia without change of the redox state of the metals; they are based on deprotonative $\mathrm{N}-\mathrm{H}$ cleavage by a $\mu_{3}$-oxo triruthenium cluster $^{[16]}$ and by a diaryl Fe complex. ${ }^{[17]}$ Furthermore, it has been shown how ammonia is activated by bifunctional iridium ${ }^{[18]}$ or ruthenium $^{[19]}$ complexes through metal-ligand cooperation. The reactions described herein proceed as well through an $\mathrm{N}-\mathrm{H}$ heterolytic cleavage of ammonia, assisted intramolecularly by a methoxo basic ligand attached to the metal. Once the amido complexes are formed, no exchange with $\mathrm{ND}_{3}$ was observed. Under mild conditions, no reaction of the terminal amido $\mathrm{Rh}$ complexes with olefins was detected. However, with terminal acetylenes, clear evidence of alkynyl complexes along with polymer formation was observed. We anticipate that diolefin amido rhodium complexes described herein catalyse very efficiently the homogeneous polymerization of phenylacetylene, being the trinuclear tfbb complex 1 much more active than the dinuclear cod complex 2 .

In conclusion, we have developed a method that allows the high yield access to $\mathrm{Rh}^{\mathrm{I}}$ and $\operatorname{Ir}^{\mathrm{I}}$ parent amido complexes directly from gaseous ammonia, creating a unique platform where to explore the reactivity and catalytic performance of these rare and relevant species. ${ }^{[20]}$ Two important points should be underlined about the synthetic strategy we enlighten here, $(i)$ it provides a direct entry into previously unknown $\mathrm{Rh}-\mathrm{NH}_{2}$ complexes, and (ii) this protocol is not limited to a specific system, but on the contrary, it may be extended to other metals bearing alkoxo bridging ligands. Finally, we believe that the ability to generate $\mathrm{M}-\mathrm{NH}_{2}$ complexes directly from ammonia follows the right direction towards the discovering of new catalytic processes involving the functionalization of ammonia, a highly desirable and valuable target that we are currently exploring.

\section{Experimental Section}

1: Gaseous ammonia was bubbled through a yellow suspension of $\left[\{\mathrm{Rh}(\mu-\mathrm{OMe})(\mathrm{tfbb})\}_{2}\right](0.25 \mathrm{~g}, 0.35 \mathrm{mmol})$ in diethyl ether $(20 \mathrm{~mL})$ at $15{ }^{\circ} \mathrm{C}$, giving rise to the crystallization of an orange microcrystalline solid within $5 \mathrm{~min}$. The bubbling of ammonia was continued for $30 \mathrm{~min}$ and the solid was collected by filtration via cannula, washed with hexanes and then vacuum-dried $(0.21 \mathrm{~g}, 88 \%)$. ${ }^{1} \mathrm{H}$ NMR $(300 \mathrm{MHz}$,
$\left[\mathrm{D}_{6}\right]$ benzene, $\left.25^{\circ} \mathrm{C}, \mathrm{TMS}\right): \delta=5.41(\mathrm{~m}, 6 \mathrm{H} ; \mathrm{CH}), 2.83(\mathrm{~m}, 12 \mathrm{H} ;=\mathrm{CH})$ (tfbb), 0.35 (br s, $\left.6 \mathrm{H} ; \mathrm{NH}_{2}\right) ;{ }^{1} \mathrm{H}$ NMR $\left(300 \mathrm{MHz}, \mathrm{CD}_{2} \mathrm{Cl}_{2},-50{ }^{\circ} \mathrm{C}, \mathrm{TMS}\right)$ : $\delta=5.89(\mathrm{~m}, 3 \mathrm{H}), 5.35(\mathrm{~m}, 3 \mathrm{H})(\mathrm{CH}), 3.38(\mathrm{~m}, 6 \mathrm{H}), 3.20(\mathrm{~m}, 6 \mathrm{H})(=\mathrm{CH})$ (tfbb), 0.44 (br s, 3H), 0.23 (br s, 3H) $\left(\mathrm{NH}_{2}\right) ;{ }^{13} \mathrm{C}\left\{{ }^{1} \mathrm{H}\right\}$ NMR $(75 \mathrm{MHz}$, $\left[\mathrm{D}_{6}\right]$ benzene, $\left.25{ }^{\circ} \mathrm{C}, \mathrm{TMS}\right): \delta=139.2\left(\mathrm{dm},{ }^{1} \mathrm{~J}(\mathrm{C}, \mathrm{F})=248 \mathrm{~Hz}\right), 138.2$ $\left(\mathrm{dm},{ }^{1} \mathrm{~J}(\mathrm{C}, \mathrm{F})=255 \mathrm{~Hz}\right)(\mathrm{CF}), 127.8\left(\mathrm{~m}, \mathrm{C}_{\mathrm{q}}\right), 52.3\left(\mathrm{~d},{ }^{1} \mathrm{~J}(\mathrm{C}, \mathrm{Rh})=10\right.$ $\mathrm{Hz} ;=\mathrm{CH}), 40.2\left(\mathrm{~d},{ }^{2} J(\mathrm{C}, \mathrm{Rh})=4 \mathrm{~Hz} ; \mathrm{CH}\right)(\mathrm{tfbb}) ;{ }^{19} \mathrm{~F}\left\{{ }^{1} \mathrm{H}\right\}$ NMR $(282$ $\mathrm{MHz},\left[\mathrm{D}_{6}\right]$ benzene): $\delta=-147.9\left(\mathrm{~d},{ }^{3} \mathrm{~J}(\mathrm{~F}, \mathrm{~F})=25 \mathrm{~Hz}\right),-160.5\left(\mathrm{~d},{ }^{3} \mathrm{~J}\right.$ $(\mathrm{F}, \mathrm{F})=25 \mathrm{~Hz}) ;{ }^{15} \mathrm{~N}-{ }^{1} \mathrm{H}$ HMQC $\left(40 \mathrm{MHz},\left[\mathrm{D}_{6}\right]\right.$ benzene, $\left.25^{\circ} \mathrm{C}, \mathrm{NH}_{3}\right): \delta=$ 5.5 (br s; $\left.\mathrm{NH}_{2}\right)$; MS $\left(\mu-\mathrm{TOF}^{+}\right): \mathrm{m} / \mathrm{z} 369.9\left(\mathrm{M}^{+} / 3+\mathrm{Na}+\mathrm{H}\right)$; elemental analysis calcd (\%) for $\mathrm{C}_{36} \mathrm{H}_{24} \mathrm{~F}_{12} \mathrm{~N}_{3} \mathrm{Rh}_{3}$ : C 41.77, $\mathrm{H}$ 2.34, $\mathrm{F} 22.02, \mathrm{~N}$ 4.06; found: C 41.65, H 2.23, F 21.95, N 4.01.

5: To a solution of $1(0.12 \mathrm{~g}, 0.12 \mathrm{mmol})$ in toluene $(4 \mathrm{~mL})$ kept at $-15{ }^{\circ} \mathrm{C}$, pure dimethylphenylphosphane $(0.05 \mathrm{~g}, 52 \mu \mathrm{L}, 0.36 \mathrm{mmol})$ was added slowly via syringe. The resulting orange solution was stirred for 15 minutes and then the volume was evaporated to dryness by reduced pressure. The resulting orange solid was washed with hexanes, filtered via cannula and dried under vacuum $(0.11 \mathrm{~g}, 61 \%)$. ${ }^{1} \mathrm{H}$ NMR (400 MHz, [D $\mathrm{D}_{8}$ ]toluene, $\left.25^{\circ} \mathrm{C}, \mathrm{TMS}\right): \delta=8.00\left(\mathrm{~m}, 2 \mathrm{H} ; \mathrm{H}_{0} \mathrm{Ph}\right)$, $7.10\left(\mathrm{~m}, 3 \mathrm{H} ; \mathrm{H}_{m}+\mathrm{H}_{p} \mathrm{Ph}\right)\left(\mathrm{PMe}_{2} \mathrm{Ph}\right), 5.49(\mathrm{~s}, 2 \mathrm{H} ; \mathrm{CH}), 3.12(\mathrm{~m}, 4 \mathrm{H}$; $=\mathrm{CH})$ (tfbb), $1.12(\mathrm{~m}, 6 \mathrm{H} ; \mathrm{Me}),-0.54\left(\mathrm{br} \mathrm{s}, 2 \mathrm{H} ; \mathrm{NH}_{2}\right) ;{ }^{1} \mathrm{H}$ NMR $(400$ $\mathrm{MHz}$, [D $\mathrm{D}_{8}$ ]toluene, $\left.25^{\circ} \mathrm{C}, \mathrm{TMS}\right): \delta=8.05\left(\mathrm{~m}, 2 \mathrm{H} ; \mathrm{H}_{o} \mathrm{Ph}\right), 7.14(\mathrm{~m}, 3 \mathrm{H}$; $\left.\mathrm{H}_{m}+\mathrm{H}_{p} \mathrm{Ph}\right)\left(\mathrm{PMe}_{2} \mathrm{Ph}\right), 5.57(\mathrm{~s}, 2 \mathrm{H} ; \mathrm{CH}), 3.18(\mathrm{~m}, 2 \mathrm{H} ;=\mathrm{CH}), 3.02(\mathrm{~m}$, $2 \mathrm{H}$; =CH) (tfbb), $1.21(\mathrm{~m}, 6 \mathrm{H} ; \mathrm{Me}),-0.36\left(\mathrm{br} \mathrm{s}, 2 \mathrm{H} ; \mathrm{NH}_{2}\right) ;{ }^{31} \mathrm{P}\left\{{ }^{1} \mathrm{H}\right\} \mathrm{NMR}$

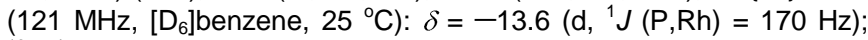
${ }^{13} \mathrm{C}\left\{{ }^{1} \mathrm{H}\right\}$-APT NMR plus HSQC (100.6 MHz, [D $\left.\mathrm{D}_{8}\right]$ toluene, $\left.-20{ }^{\circ} \mathrm{C}, \mathrm{TMS}\right)$ : $\delta=142.1\left(\mathrm{dd},{ }^{1} \mathrm{~J}(\mathrm{C}, \mathrm{P})=18 \mathrm{~Hz},{ }^{2} \mathrm{~J}(\mathrm{C}, \mathrm{Rh})=17 \mathrm{~Hz} ; \mathrm{C}_{\text {ipso }} \mathrm{Ph}\right), 139.9$ $\left(\mathrm{dm},{ }^{1} \mathrm{~J}(\mathrm{C}, \mathrm{F})=242 \mathrm{~Hz}\right), 138.2\left(\mathrm{dm},{ }^{1} \mathrm{~J}(\mathrm{C}, \mathrm{F})=269 \mathrm{~Hz}\right)(\mathrm{CF} \mathrm{tfbb})$, $131.63\left(\mathrm{dd},{ }^{2} \mathrm{~J}(\mathrm{C}, \mathrm{P})=6 \mathrm{~Hz},{ }^{3} \mathrm{~J}(\mathrm{C}, \mathrm{Rh})=6 \mathrm{~Hz} ; \mathrm{C}_{0}\right), 128.7\left(\mathrm{~s}, \mathrm{C}_{p}\right), 127.6$ $\left(\mathrm{d},{ }^{3} \mathrm{~J}(\mathrm{C}, \mathrm{P})=4 \mathrm{~Hz} ; \mathrm{C}_{m}\right)(\mathrm{Ph}), 48.5\left(\mathrm{~d},{ }^{1} \mathrm{~J}(\mathrm{C}, \mathrm{Rh})=10 \mathrm{~Hz} ;=\mathrm{CH}\right), 40.3$ (d, $\left.{ }^{2} J(\mathrm{C}, \mathrm{Rh})=3 \mathrm{~Hz} ; \mathrm{CH}\right)(\mathrm{tfbb}) ;{ }^{19} \mathrm{~F}\left\{{ }^{1} \mathrm{H}\right\} \quad \mathrm{NMR} \quad(282 \mathrm{MHz}$, [D $\left.\mathrm{D}_{6}\right]$ benzene): $\delta=-144.4\left(\mathrm{~d},{ }^{3} \mathrm{~J}(\mathrm{~F}, \mathrm{~F})=23 \mathrm{~Hz}\right),-157.1\left(\mathrm{~d},{ }^{3} \mathrm{~J}(\mathrm{~F}, \mathrm{~F})=\right.$ $25 \mathrm{~Hz}) ;{ }^{15} \mathrm{~N}-{ }^{1} \mathrm{H}$ HMQC $\left(40 \mathrm{MHz},\left[\mathrm{D}_{6}\right]\right.$ benzene, $\left.25{ }^{\circ} \mathrm{C}, \mathrm{NH}_{3}\right): \delta=-11.8$; MS $\left(\mu-\mathrm{TOF}^{+}\right): \mathrm{m} / \mathrm{z} 467.0\left(\mathrm{M}^{+}-\mathrm{NH}_{2}\right)$; elemental analysis calcd $(\%)$ for $\mathrm{C}_{20} \mathrm{H}_{19} \mathrm{~F}_{4}$ NPRh: C 49.71, H 3.96, N 2.90; found: C 49.68, H 3.89, N 2.81 .

Received: ((will be filled in by the editorial staff))

Published online on ((will be filled in by the editorial staff))

Keywords: ammonia $\cdot$ parent amido $\cdot$ rhodium $\cdot$ iridium $\cdot \mathrm{N}-\mathrm{H}$ activation

[1] a) J. I. van der Vlugt, Chem. Soc. Rev. 2010, 39, 2302-2322; b) Y. Aubin, C. Fischmeister, C. M. Thomas, J. -L. Renaud, Chem. Soc. Rev. 2010, 39, 4130-4145.

[2] J. L. Klinkenberg, J. F. Hartwig, Angew. Chem. Int. Ed. 2011, 50, 8695.

[3] T. Braun, Angew. Chem. Int. Ed. 2005, 44, 5012-5014.

[4] a) A. L. Casalnuovo, J. C. Calabrese, D. Milstein, Inorg. Chem. 1987, 26, 971-973; b) R. Koelliker, D. Milstein, Angew. Chem. Int. Ed. 1991 30, 707-709; c) M. Schulz, D. Milstein, J. Chem. Soc., Chem. Commun. 1993, 318-319; d) R. Koelliker, D. Milstein, J. Am. Chem. Soc. 1991, 113, 8524-8525.

[5] J. Zhao, A. S. Goldman, J. F. Hartwig, Science 2005, 307, 1080-1082.

[6] a) E. Morgan, D. F. MacLean, R. McDonald, L. Turculet, J. Am. Chem. Soc. 2009, 131, 14234-14236; b) M. A. Salomon, A. -K. Jungton, T. Braun, Dalton Trans. 2009, 7669-7677; c) C. M. Fafard, D. Adhikari, B. M. Foxman, D. J. Mindiola, O. V. Ozerov, J. Am. Chem. Soc. 2007, 129, 10318-10319; d) P. Kläring, S. Pahl, T. Braun, A. Penner, Dalton Trans. 2010, 40, 6785-6791.

[7] a) C. Tejel, M. A. Ciriano, M. Bordonaba, J. A. López, F. J. Lahoz, L. A. Oro, Inorg. Chem. 2002, 41, 2348-2355; b) J. J. Li, W. Li, A. J. James, T. Holbert, T. P. Sharp, P. R. Sharp, Inorg. Chem. 1999, 38, 1563-1572.

[8] Data for 1: $\mathrm{C}_{36} \mathrm{H}_{24} \mathrm{~F}_{12} \mathrm{~N}_{3} \mathrm{Rh}_{3} \cdot \mathrm{C}_{6} \mathrm{H}_{14}, M=1121.48$, space group $P 2_{1} / n$, $a=13.5763(8), b=13.3187(8), c=21.4824(13) \AA ; \beta=99.062(2)^{\circ} ; V$ $=3835.9(4) \AA^{3} ; Z=4 ; R_{l}=0.0344,9620$ refl., $I>2 \sigma(I) ; w R\left(F^{2}\right)=$ 0.0880, GoF $=1.033$ (10940 unique). Data for 2: $\mathrm{C}_{36} \mathrm{H}_{24} \mathrm{~F}_{12} \mathrm{~N}_{3} \mathrm{Ir}_{3}$. 
$\mathrm{C}_{6} \mathrm{H}_{14}, M=1389.42$, space group $P 2_{1} / n, a=13.5872(6), b=$ 13.3741(6), $c=21.3459(10) \AA ; \beta=98.951(1)^{\circ} ; V=3831.7(3) \quad \AA^{3}$; $Z=4 ; R_{I}=0.0262,8669$ refl., $I>2 \sigma(I) ; w R\left(F^{2}\right)=0.0680$, GoF $=1.019$ (9967 unique). Data for 3: $\mathrm{C}_{16} \mathrm{H}_{28} \mathrm{~N}_{2} \mathrm{Rh}_{2}, M=454.22$, space group $P-1$, $a=6.9014(4), \quad b=11.6776(7), \quad c=21.2575(13) \AA \AA \alpha=$ $104.3290(10), \beta=98.7070(10)^{\circ} ; \gamma=90.4370(10)^{\circ}, V=1638.9(2) \quad \AA^{3} ;$ $Z=4 ; R_{l}=0.0208,7277$ refl., $I>2 \sigma(I) ; w R\left(F^{2}\right)=0.0706, G o F=1.002$ (8225 unique). CCDC 831649,831650 and 831651 contain the supplementary crystallographic data for this paper. These data can be obtained free of charge from The Cambridge Crystallographic Data Centre via www.ccdc.cam.ac.uk/data_request/cif.

[9] B. Lippert, P. J. Sanz Miguel, Chem. Soc. Rev. 2011, 40, 4475-4482.

[10] C. Tejel, M. A. Ciriano, M. Bordonaba, J. A. López, F. J. Lahoz, L. A. Oro, Chem. Eur. J. 2002, 8, 3128-3138.

[11] a) S. Ragone, A. Poater, L. Cavallo, J. Am. Chem. Soc. 2010, 132, 4249-4258; b) C. L. Vélez, P. R. L. Markwick, R. L. Holland, A. G. DiPasquale, A. L. Rheingold, J. M. O'Connor, Organometallics 2010, 29, 6695-6702; c) V. Ritleng, C. Barth, E. Brenner, S. Milosevik, M. J. Chetcuti, Organometallics 2008, 27, 4223-4228.

[12] a) J. R. Fulton, A. W. Holland, D. J. Fox, R. G. Bergman, Acc. Chem. Res. 2002, 35, 44-56; b) M. Rahim, C. White, A. L. Rheingold, K. J. Ahmed, Organometallics 1993, 12, 2401-2403; c) M. K. Kolel-Veetil, M. Rahim, A. J. Edwards, A. L. Rheingold, K. J. Ahmed, Inorg. Chem. 1992, 31, 3877-3878.

[13] a) J. L. Klinkenberg, J. F. Hartwig, J. Am. Chem. Soc. 2010, 132, 11830-11833; b) D. J. Fox, R. G. Bergman, Organometallics 2004,
23, 1656-1670; c) J. Cámpora, P. Palma, D. del Río, M. M. Conejo, E. Álvarez, Organometallics 2004, 23, 5653-5655; d) D. J. Fox, R. G. Bergman, J. Am. Chem. Soc. 2003, 125, 8984-898; e) A. W. Kaplan, J. C. M. Ritter, R. G. Bergman, J. Am. Chem. Soc. 1998, 120, 68286829.

[14] M. Kanzelberger, X. Zhang, T. J. Emge, A. S. Goldman, J. Zhao, C. Incarvito, J. F. Hartwig, J. Am. Chem. Soc. 2003, 125, 13644-13645.

[15] a) D. Conner, K. N. Jayaprakash, T. R. Cundari, T. B. Gunnoe, Organometallics 2004, 23, 2724-2733; b) A. W. Holland, R. G. Bergman, J. Am. Chem. Soc. 2002, 124, 14684-14695; c) K. N. Jayaprakash, D. Conner, T. B. Gunnoe, Organometallics 2001, 20 , 5254-5256; d) F. L. Joslin, M. P. Johnson, J. T. Mague, D. M. Roundhill, Organometallics 1991, 10, 2781-2794.

[16] Y. Nakajima, H. Kameo, H. Suzuki, Angew. Chem. Int. Ed. 2006, 45, 950-952.

[17] C. Ni, H. Lei, P. P. Power, Organometallics 2010, 29, 1988-1991.

[18] T. Kimura, N. Koiso, K. Ishiwata, S. Kuwata, T. Ikariya, J. Am. Chem. Soc. 2011, 133, 8880-8883.

[19] E. Khaskin, M. A. Iron, L. J. W. Shimon, J. Zhang, D. Milstein, J. Am. Chem. Soc. 2010, 132, 8542-8543.

[20] a) J. F. Hartwig, Nature 2008, 455, 314-322; b) T. E. Müller, K. C. Hultzsch, M. Yus, F. Foubelo, M. Tada, Chem. Rev. 2008, 108, 37953892 . 


\section{Entry for the Table of Contents}

\section{Parent Amido Complexes}

Inmaculada Mena, Miguel A. Casado,*

Pilar García-Orduña, Víctor Polo,

Fernando J. Lahoz, Atif Fazal and Luis

A. Oro*

Page - Page

Direct Access to Parent Amido

Complexes of Rhodium and Iridium through N-H Activation of Ammonia

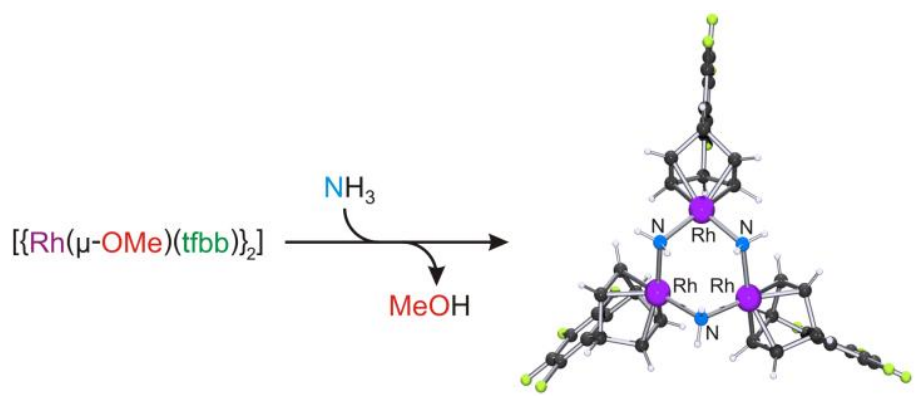

Simplicity! A direct entry to parent amido $d^{8}$ rhodium and iridium complexes was easily achieved by interaction of gaseous ammonia with alkoxo-bridged precursors under very mild conditions. This new approach allows the high yield access for the first time to elusive $\left[\mathrm{Rh}-\mathrm{NH}_{2}\right]$ complexes. 